\title{
Conditional Vulnerability in the Films of Ruben Östlund
}

\author{
Asbjørn Grønstad
}

In August, tornadoes caused by the tropical storm Harvey ravage the Houston area. In September, a major earthquake strikes Mexico City. In October, a mass murderer butchers 58 people and injures almost 500 others from his hotel window in Las Vegas. Later the same month, an uncontrollable wildfire in the Santa Rosa area north of San Francisco kills over 40 people and destroys thousands of homes. These disasters, which take place within the span of six to seven weeks in the early fall of 2017, transpire against the backdrop of a rapidly accelerating environmental crisis and-with seemingly mentally ill political leaders in North Korea and the USA - the perhaps most perilous geopolitical condition in recent memory. Rarely has it made more sense to consider one of the most defining circumstances of our lives, both as individuals and as a species. That circumstance is vulnerability.

Cataclysmic events tend to place the condition of being existentially exposed on the agenda, as when Judith Butler wrote about precarious life

\footnotetext{
A. Grønstad ( $\otimes)$

University of Bergen, Bergen, Norway

e-mail: asbjorn.gronstad@uib.no

(C) The Author(s) 2020

A. M. Dancus et al. (eds.),
}

Vulnerability in Scandinavian Art and Culture, https://doi.org/10.1007/978-3-030-37382-5_2 
in the wake of $9 / 11$, and the invasions of Afghanistan and Iraq. In her book from 2004, she relates precariousness to the process of coping with 'a sudden and unprecedented vulnerability' (Butler 2004, p. 42). 'Precarious' as a critical term has also been associated with the work of Bourriaud (2009) and Foster (2009). But however much extreme occurrences serve to emphasize our vulnerability, the condition itself is permanent and universal, although its rate of attrition is, of course, unevenly distributed across the continents. To study states of vulnerability along with their causes and properties is certainly a burning issue for researchers from many fields, from the natural sciences to the humanities, but my main interest in this chapter is, rather, the fictional treatment of the individual's response to the condition of being vulnerable. Building on my previous studies of the complex imbrication of aesthetics and ethics, of how artistic expressions may renew and even transform our ethical insights (cf. Grønstad 2016), I want to turn toward a small group of feature films to see if they may teach us something about dealing with vulnerability that escapes more anthropological approaches.

One of the contemporary filmmakers who have explored what I propose to call the aesthetics of vulnerability most consistently is the Swedish director Ruben Östlund. With a handful of well-received feature films such as Involuntary (2008), Play (2011), Force Majeure (2014) and The Square (2017) to his credit, Östlund has during that time emerged as possibly the foremost chronicler of social unease and moral precarity in Scandinavian cinema. In Involuntary, Östlund examines the psychology of peer pressure; in Play, questions of race, class and political correctness; in Force Majeure, problems of contemporary masculinity; and, finally, in The Square, the delusions and hypocrisy of the art world. What is shared by all his films is an unusual sensitivity to the ways in which everyday life may be upended by unexpected events that pose an existential threat to the characters and their worldviews. In the cinematic universe Östlund constructs, the condition that is most particularly scrutinized is that of exposure; the sense of losing the (cultural as well as material) privilege of protection and finding oneself unshielded from unpleasant and invasive forces from outside. The key post-millennial film to address this issue is arguably Caché (Michael Haneke 2005), in which the comfortable life of a successful television host is made precarious by encroaching circumstances from his own past. What I have elsewhere referred to as Haneke's cinema of intrusion is an important precursor to Östlund's project (Grønstad 2012), which retains elements both of Haneke's style and his themes to forge, on the 
Swedish director's own terms, a cinema of vulnerability specifically situated within a Scandinavian cultural context. This chapter considers the process and experience of vulnerability, and how it is inscribed into the aesthetic fabric of Östlund's films.

Questions of vulnerability are often identified with a set of interrelated concepts such as precariousness, suffering, susceptibility, affectability, dependency and responsibility. Leading scholars in the emergent field of vulnerability studies have grappled with issues such as the ontology of vulnerability (Catriona Mackenzie, Wendy Rogers and Susan Dodds), the vulnerable subject and its potential for replacing the category of the legal actor (Martha Fineman), the idea of a feminine economy that reconstitutes vulnerability as strength (Erinn Gilson drawing on Hélène Cixous), and the relation between vulnerability and resistance (Judith Butler). Most of these approaches also operate within the larger domain of ethics. What I purport to do here is not only to extend the discussion of vulnerability into the realm of aesthetics, but also to put it into contact with a concept that, at first, may seem surprising, perhaps even counterintuitive. That concept is privilege. Disenfranchised groups are obviously vulnerable. If by chance we happen to find ourselves in the midst of a natural disaster such as an earthquake or a tornado, we are also undoubtedly vulnerable.

But vulnerability can also be contingent on forces that are less patently socio-economic, political, or environmental. In cases in which privilege and entitlement are threatened, vulnerability may assume an existential foundation. For some critics, the notion of vulnerability has to be put into quotation marks when it is applied; for instance, in the context of a fear of immigration or feminism (Butler et al. 2016, p. 4). But does this 'performed' sense of vulnerability not deserve to be taken seriously? I would like to suggest that this inauthentic or artificial vulnerability is valuable precisely as an index of the logic of privilege. The loss of privilege is presumably perceived and felt as a real thing, so maybe inauthentic is not the best term from a phenomenological point of view, but this form of vulnerability is nonetheless markedly different from that discussed in the scholarly literature referred to above. Call it conditional vulnerability, a special kind of precarity that ensues from the erosion of advantages that may not have been entirely warranted in the first place. Psychoanalytically inspired feminism, Butler et al. (2016, p. 4) write, has suggested that 'the masculine positions are effectively built through a denial of their own vulnerability. This denial or disavowal requires one to forget one's own vulnerability and project, displace, and localize it elsewhere.' The 
prospect of losing one's privileges does introduce a degree of actually felt vulnerability into the life of the subject, no matter how ideologically odious these privileges are. The privileges of wealth, race and gender work to preclude vulnerability. When they come under threat, the subject is exposed to the same general vulnerability that is a condition of life for the disenfranchised. This exposure could no doubt generate frustration, violence and attempts to project vulnerability onto other people, but it could also, in the best of circumstances, lead to a better acknowledgement of and empathy with the suffering of others. My contention is that aesthetic works, in compressing, narrativizing and fine-tuning experiences of vulnerability, can contribute insights that are beneficial for our ethical reflections on the subject.

While Haneke may have been one of the first filmmakers systematically and unflinchingly to probe the fraught intersection of cultural privilege and vulnerability, Östlund has been the one to take up the mantle in a series of features that, in quite subtle ways, reveal the fear and helplessness that quickly arise when white masculinity comes under siege. Östlund's cinema is also effective in encapsulating the feeling of being exposed, as the sense of a looming and possibly accelerating threat is incorporated into the very style of his films. In Play, for example, the general eschewal of shot-reverse-shot structures and the preference for the use of a zoom lens and long takes that have characters saunter in and out of the frame create an abiding sense of tension and peril. Described by one critic as an aesthetic of detachment that is at once physically calm yet optically nervous (Coldiron 2011), Play is a work that deals with social discomfort and anxiety on both a narrative and a thematic level. Based on allegedly real incidents in Gothenburg, the film depicts the intimidation of two white kids and one Asian by five black adolescents. The latter group has devised an elaborate role-play scheme to divest the former group of their phones, who for fear of appearing politically incorrect get increasingly embroiled in the scam. A controversial feature about the cultural psychology of racial profiling, Play engages with a host of intersecting issues in which vulnerability appears to be a constituent part-identity, immigration, race, class, harassment and manipulation. As I will argue, the film may be read as a story about not only corporeal vulnerability and the threat of imminent violence, but also about the vulnerability that results from having one's cultural privileges suspended, even that of political correctness.

Mobile phones also play a distinguished role in Östlund's next project, his international breakthrough movie Force Majeure. Set in the French 
Alps, the film's narrative charts the dissolution (and possible reconciliation) of a Swedish upper-middle-class family vacationing at the magnificent Les Arcs ski resort. On their second day there, something out of the ordinary takes place. Having lunch at the rooftop restaurant, the family are watching a controlled avalanche gather so much momentum toward the dining area that they mistakenly believe it is going to consume them. Chaos and panic follow. The screen goes momentarily blank from the whiteness of the snow, yet there is no mistaking the instinctive gestures and action of Tomas (Johannes Kuhnke), the family father. Unmindful of the immediate well-being of his wife and children, Tomas grabs his cell phone and gloves and makes a swift escape. The avalanche stops just in time and nobody is injured but its effect will linger on throughout the rest of the film. Later the same day, during dinner with another couple, Tomas's wife Ebba (Lisa Kongsli) shares the story, emphasizing her husband's somewhat less than heroic behaviour during the avalanche. Tomas categorically rejects her version of the events, thus making matters even worse.

Both Play and Force Majeure hone in on the unnerving friction that evolves out of fairly everyday situations, although, in the case of the latter film, the incident that sparks the drama may itself be unusual. The kind of conditional vulnerability Östlund unveils is not straightforwardly covered by the terms introduced by philosophers Catriona Mackenzie and her colleagues $(2014$, p. 4$)$ (inherent, situational, pathogenic), which seem too broad. ${ }^{1}$ Tomas's anguish may appear context-specific on the surface but betrays a deeper sense of cultural conditioning that involves a messy interaction between the norms, expectations, and privileges associated with a particular form of masculinity. Force Majeure also represents an especially salient case of working through vulnerability in visual fiction, as it features one of the most spectacular male breakdowns in all of cinema. Portraying in unsparing detail a despondent trajectory from an initial act of selfishness to a complete emotional collapse, Östlund's film comes across almost as an inversion of the narrative arc of Straw Dogs (1971), Sam Peckinpah's perennially scandalous investigation into the nexus of masculinity and violence. While Dustin Hoffman's character in that film starts off as an emasculated American academic out of his depth in a hardened working-class environment in rural Britain, only to regain a sense of primitive masculinity through a momentous act of violence, Tomas in Force Majeure is an alpha male, privileged in all ways imaginable, who gradually comes apart at the seams in a starkly unflattering manner. 
Ebba's simmering disapproval of her husband's comportment during and after the avalanche is the motor of Östlund's psychodrama, whose unflinching gaze at marital discord owes something not only to Haneke, but also to Ingmar Bergman. As viewers we will never know whether the relationship between Tomas and Ebba was turbulent even before the crisis, but the perfect family façade from the opening scenes seems irreparably damaged not only by Tomas's thoughtlessness/cowardice, but also by his pathetic lies in the aftermath of the event. Even though the film's ambiguous ending may suggest a glimmer of hope for the couple, the relationship Östlund captures with both cynical precision and elements of comedy is one progressively tainted by Ebba's mounting contempt. What the film essentially dissects is how that contempt subtly materializes in the strained interactions between the couple, until it culminates in the scene where Tomas breaks down in front of his family, howling uncontrollably. Rarely has humiliated masculinity been shown in such an uncompromising way on screen. The moment also spells the end of Tomas's state of denial and his entry into a condition of naked vulnerability.

Pivotal as this scene is, it is not the only cinematic figuration of vulnerability in Force Majeure. Östlund takes advantage of the film's setting to compose a series of tableaux that disclose the inconsequentiality of the human against the backdrop of the immense alpine landscape. 'The family are nothing more than ants', one critic observes, 'and it's the little things that collapse the supposed edifices that they construct' (Gnanalingam 2014). Comparing Östlund's visual and thematic orientation to that of Michelangelo Antonioni-an influence seen, for instance, in the former's interest in the nature of existential discontent-the same reviewer notes that it is 'the impassive natural landscapes that dominate the puny human attempts to tame it' (Gnanalingam 2014). Several of the interior scenes are likewise set up to accentuate the potential defencelessness of the family, as in the shot of the four of them sleeping in the same bed, fully clothed and drained after the day's activities. Östlund's handling of film space to convey a sense of uneasiness and apprehension is also reflected in his frequent withholding of reverse shots, as in the scene from The Square in which Michael is waiting in the car near the housing projects and we never see the person who knocks on the window and talks to him.

As an aesthetic medium, cinema is uniquely positioned to address states of vulnerability, among other things because its chief substance is the human body and its interaction with a given environment. Entire genre ecologies are based on the inherent frailty of that body, from disaster 
movies to action spectacles and horror films. Furthermore, the kinds of drama films associated with modernist art cinema and with filmmakers such as Antonioni, Rossellini, Bergman, Ozu, Resnais, Tarkovsky and many others also sometimes act as vehicles for the artistic examination of subjectivity under duress. Contemporary directors such as Haneke and Östlund are, in various ways, indebted to this tradition; but, they also renew it through their more or less implicit yet sustained critique of cultural privilege, currents of entitlement tied to class, gender and ethnicity.

Östlund's acidic art-world satire The Square, his follow-up to Force Majeure, may be read as an enquiry into the ethical ramifications of this sense of privilege, using experiences of vulnerability as a wedge. Again, the spatial dimension is prominent. The eponymous object of the film's title is a small gathering place outside a fictional art museum in Stockholm, described by its plaque as 'a sanctuary of trust and caring' and as a space where everyone has 'equal rights and obligations'. An instance of participatory art that also seems to nod to Nicolas Bourriaud's (2002) notion of relational aesthetics, 'The Square' is designed to be an installation for the cultivation of empathy. But the context for this project is an art establishment infected by a hypocrisy so deep and systemic that it has become virtually second nature. Oblivious to the social affliction around him, Christian (Claes Bang), the museum's arrogant and occasionally clueless director, comes to personify a perspective wherein the best moral intentions have lost any connection to material reality. But Östlund, like Haneke, is not content merely to expose this institutional insincerity; he also wants to see what happens when the infrastructures of respectability and privilege disintegrate, and the ostensibly unassailable become vulnerable just like the rest. There are two events in The Square that, in particular, pursue this objective: the theft of Christian's phone and wallet, and the repercussions his ill-conceived attempt at getting them back will have; and the aggressive disruption of a formal dinner by a performance artist.

What kind of ethics, then, if any, does Östlund's cinema encapsulate? My thesis is that films such as Force Majeure and The Square dramatize and give aesthetic shape to the conceptual transition, promoted by Martha Fineman and Anna Grear (2013, p. 4), from the idea of the legal actor or 'unencumbered self' - 'the rational, property-owning actor at the heart of classic liberalism' - to the idea of the vulnerable subject. Vulnerability is not primarily about emotional or physical distress but about the receptivity for insight. In Erinn C. Gilson's (2014) words, vulnerability is 'an 
experience born of discomfort with the unfamiliar, the uncontrolled, or the unpredictable', but, she adds, 'only through muddling about in this experience do we learn, change, and extend ourselves beyond our current limits' (p. 127). Because fiction, practically by definition, harbours the dramatic as part of its core structure, it is particularly suited to capturing the intricacies of this experience.

Christian in The Square - and, by extension, the social world in which he is enmeshed-perfectly embody this confrontation between the unencumbered self and the vulnerable subject. Prior to the curious events that unfold in the film's narrative, any infringement on the privileges and benefits of this sheltered sphere would be wholly inconceivable to someone like Christian. To rub in the disparity between this sphere and that of sheer precarity found outside the walls of the museum, the film resorts to some rather heavy-handed juxtapositions of cultured affluence and homelessness on the streets of Stockholm. More subtle is the suggestiveness of the film's titular object, the 'installation' that comes to represent 'a sanctuary of trust and caring' in which all have 'equal rights and obligations'. On one level, the square metaphorizes one of the functions that the museum as an institution already has, which is that of a temporary sanctuary and space of escapism from the harsher realities of the world outside (an idea entertained in Jem Cohen's Museum Hours from 2012). ${ }^{2}$ From this point of view, the very notion of such an installation appears disingenuous, more than anything an unnecessary and self-congratulatory gesture whose ethical vacuity is borne out by Christian's less than noble actions, which-contrary to the idealism of his art project-are mostly distrustful and uncaring. It moreover seems unlikely that Östlund would be unaware of Jehane Noujaim's award-winning and critically lauded documentary of the same name, which premiered at Sundance in 2013 and which deals with Tahrir Square and the revolution in Egypt that began in January of 2011. On a different level, then, the square in Östlund's film designates a place where, unlike that of Tahrir, nothing much is really at stake. This troubled and politically charged tension between the warm and fuzzy square of the white, western and predominantly male art world on the one hand and, on the other, the unsafe square in which real struggle takes place could be further contextualized by the colonial histories of the art museum. The first objects in Britain's National Gallery, for instance, were purchased from the collection of John Julius Angerstein, a prominent banker and Caribbean plantation owner (see Conlin 2006). 
But as it turns out, in Östlund's movie the rarefied sanctuary that is the modern art gallery ceases, at least temporarily, to be a safe place for the over-privileged western subject. In the film's set piece, anarchic forces foreign to the habitus of the art world erupt onto the scene of a formal dinner party. As entertainment someone has brought a performance artist who, during a dazzling 11-minute scene, intimidates the gala guests with his progressively antagonistic routine as a deranged chimpanzee. As an introduction, an acousmêtre announces that the partygoers will soon be 'confronted by a wild animal' trained to sense their vulnerability and fear. In comes the grunting, shirtless Oleg, played by American stunt actor Terry Notary, whose act is inspired by the transgressive hardcore rocker GG Allin. At first, Oleg appears a bit apprehensive. Before long he is turning assertive, prowling among the tables on all fours, barking and growling, taunting his chosen victims and chasing the party's alpha male out of the room. Careful to include reaction shots of the befuddled and increasingly disconcerted guests, throughout the elongated and intricate sequence Östlund ups the ante by making Oleg's behaviour progressively more threatening and unpredictable. Twice the guests applaud the performance, most likely as a futile attempt to cut short the show and, along with it, their own dismay. But Oleg continues undeterred. Chasing away a few more guests, he jumps up on a table. The room has gone quiet, and everyone stares at their hands. Perched atop the table, Oleg notices a red-haired woman, whom he proceeds to fondle before abruptly and brutally pulling her off her chair and dragging her across the floor. As what is surely one of the most uncomfortable scenes in all of cinema reaches its climax, Oleg tries to rape the woman but an elderly gentleman intervenes. Finally confronted, Oleg the ape man is attacked by a mob that pummels him relentlessly.

This scene, which took four days to shoot and involved dozens of takes with an ensemble of extras consisting of artists and curators, condenses multiple issues involving white male privilege. First, it divulges the naked vulnerability of cultured and affluent masculinity when faced with unanticipated and erratic forces beyond its horizon of experience. This is a theme with a certain family resemblance to Haneke's Caché, in which the external menace is associated with the subaltern, and to Force Majeure, where a natural phenomenon occasions a psychological collapse on part of the seemingly insusceptible white male. The figure of Oleg the monkey man in a way epitomizes both these senses of intrusion, the culturally Other whose mode of operation causes havoc the repercussions of which 
seem akin to a natural disaster. Second, when the male guests at the gala dinner finally act, their response prompts a breakdown of social convention no less disturbing than Oleg's own behaviour. The enraged men are not content merely to defuse the escalating chaos by subduing Oleg, but keep on hysterically pounding him (the actor broke a toe while shooting the scene). Rarely has the veneer of civilized conduct been shown to be this thin. The conformity that prevents the guests from interceding any sooner seems to be the same conformity that just a little later transforms them into a seething, mad mob. Discussing the scene, the director himself has stated that ' $[t]$ he reason we don't have the ability to take responsibility in situations like that is because we are herd animals and we get scared, and when we get scared we get paralyzed' (Östlund quoted in Yuan 2018). For the kind of masculinity that Christian and his peers represent, it could be argued that the gravest risk, however, is not Oleg's potential for doing violence to their bodies but, rather, his power to elicit precisely those reactions that would undermine their professional identities and self-understanding.

As part of a (gendered) elite for whom there is no contradiction between neglecting the homeless while pursuing a project centred on values such as trust and caring, Christian is obviously a 'modern hypocrite', to borrow the language of one critic, 'idealistic in his words and cynical in his deeds' (Jakobson 2017). This psychological chasm, which has become practically second nature to Christian, propels a failure of personal ethics. That his project 'The Square' is a flagrant example of what the French curator and art critic Nicolas Bourriaud has termed relational art is deeply ironic (Bourriaud 2002), since Christian seems constitutively unable to grasp the nature of the various social and institutional entanglements of which he is a part. The beggars that line the streets of his immediate environs are simply invisible to him, and his poor judgement in dealing with the people he suspects may have stolen his phone and wallet betrays a lack of interpersonal sensitivity. The extent to which Christian seems disconnected both from other people and from the consequences of his own actions is demonstrated in a comically absurd scene in which he insists on disposing of his own used condom after being with the journalist Anne (Elisabeth Moss). Again, Christian indicates through his egotistic behaviour that he is either unaware of or indifferent towards the ways in which his life is entwined with those of others.

By now, it may have become clear that what I refer to above as conditional vulnerability may be a force of productive change in milieus 
such as that depicted in The Square. For Östlund's advantaged white men, the process of having their self-centredness exposed and their privileges challenged results in crises whose attendant new insights could only be attained through becoming vulnerable. While there is a rich tradition in the arts for direct and unswerving portrayals of existential, corporeal vulnerability - from the work of artists such as Hannah Wilke, Felix Gonzales-Torres, Derek Jarman and David Wojnarowicz, to recent projects such as Lata Mani and Nicolás Grandi's The Poetics of Fragility (2016) - Östlund's films zero in on a different form of engaging with vulnerability, one that would seem to prove the validity of Gilson's (2014) thesis that 'being vulnerable, openness to being affected and affecting, is the basic precondition for experience' (p. 14l). But for the kind of ossified masculinity that a character such as Christian signifies, this potential for receptivity needs some sort of catalyst from without, be it a mysterious videotape, an avalanche, or a human ape. If an ethics emerges from the moral laboratories of Haneke and Östlund, it is one closely aligned with what Wendy Brown (1988) once termed 'post-masculinist politics', a rejection of instrumentalist notions of rationality grounded in a pathological need to control and dominate one's environment. The prescience of The Square, made previous to but released stateside just after the \#metoo movement exploded and mere months before the Swedish Nobel Academy scandal broke, finally also relates it to Joanna Zylinska's (2014) critique of stale masculinist positions ill-equipped to handle what she calls a 'post-anthropocentric ethics of expanded obligations' (p. 17). This is an ethics unthinkable without vulnerability.

\section{Notes}

1. In the work of these critics, 'inherent' vulnerability designates a corporeal condition that is universally shared, whereas 'pathogenic' vulnerability extends to subjects that are already disadvantaged due to various disabilities, corporeal as well as mental. 'Situational' vulnerability comes closer to my own term, 'conditional' vulnerability, as it refers to aspects of the subject's social or political environment. I would argue that the term nonetheless is too imprecise for the kind of vulnerability that I try to capture here, which is, first, symbolic more than material and, second, is articulated through aesthetic processes, rather than through the direct experiences of actual subjects. 
2. For an analysis of the depiction of the museum in Cohen's film, see Asbjørn Grønstad, 'Museum movies, documentary space, and the transmedial', in Documenting the Visual Arts, ed. Roger Hallas, 2019.

\section{REFERENCES}

Albertson Fineman, M., \& Grear, A. (2013). Introduction: Vulnerability as heuristic-An invitation to future exploration. In M. Albertson Fineman \& A. Grears (Eds.), Vulnerability: Reflections on a New Ethical Foundation for Law and Politics. Farnham: Ashgate.

Bourriaud, N. (2002). Relational Aesthetics (S. Pleasance \& F. Woods, Trans.). Dijon: Presses du reel.

Bourriaud, N. (2009). The Radicant: No. 17. New York: Sternberg Press.

Brown, W. (1988). Manhood and Politics: A Feminist Reading in Political Theory. Totowa, NJ: Rowman and Littlefield.

Butler, J. (2004). Precarious Life: The Powers of Mourning and Violence. London: Verso.

Butler, J., Gambetti, Z., \& Sabsay, L. (2016). Introduction. In J. Butler, Z. Gambetti, \& L. Sabsay (Eds.), Vulnerability in Resistance. Durham: Duke University Press.

Coldiron, P. (2011, October 15). Play. Slant Magazine. https://www. slantmagazine.com/film/review/play. Accessed 3 November 2017.

Conlin, J. (2006). The Nation's Mantelpiece: A History of the National Gallery. London: Pallas.

Foster, H. (2009, December). Precarious. Artforum, pp. 207-209.

Gilson, E. C. (2014). The Ethics of Vulnerability: A Feminist Analysis of Social Life and Practice. New York: Routledge.

Gnanalingam, B. (2014, August 5). God complex: The reunion, force majeure. The Lumière Reader. http://lumiere.net.nz/index.php/the-reunion-forcemajeure/. Accessed 8 November 2017.

Grønstad, A. (2012). Screening the Unwatchable: Spaces of Negation in Postmillennial Art Cinema. Basingstoke: Palgrave Macmillan.

Grønstad, A. (2016). Film and the Ethical Imagination. Basingstoke: Palgrave Macmillan.

Grønstad, A. (2019). Museum movies, documentary space, and the transmedial. In R. Hallas (Ed.), Documenting the Visual Arts. London: Routledge.

Jakobson, C. (2017). Ruben Östlund's The Square: The art of being human. Fourbythreemagazine. http://www.fourbythreemagazine.com/cannes-filmfestival-2017/ruben-ostlund-the-square. Accessed 9 November 2018.

Mackenzie, C., Rogers, W., \& Dodds, S. (2014). Introduction: What is vulnerability, and why does it matter for moral theory? In C. Mackenzie, W. Rogers, 
\& S. Dodds (Eds.), Vulnerability: New Essays in Ethics and Feminist Philosophy. Oxford: Oxford University Press.

Yuan, J. (2018, 6 November). The Square's monkey-man scene is bonkers. Here's how it was made. Vulture. http://www.vulture.com/2017/11/how-thesquares-bonkers-monkey-man-scene-was-made.html. Accessed 7 May 2018.

Zylinska, J. (2014). Minimal Ethics for the Anthropocene. Ann Arbor: Open University Press.

Open Access This chapter is licensed under the terms of the Creative Commons Attribution 4.0 International License (http://creativecommons.org/licenses/ by $/ 4.0 /)$, which permits use, sharing, adaptation, distribution and reproduction in any medium or format, as long as you give appropriate credit to the original author(s) and the source, provide a link to the Creative Commons license and indicate if changes were made.

The images or other third party material in this chapter are included in the chapter's Creative Commons license, unless indicated otherwise in a credit line to the material. If material is not included in the chapter's Creative Commons license and your intended use is not permitted by statutory regulation or exceeds the permitted use, you will need to obtain permission directly from the copyright holder.

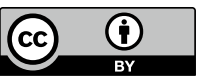

